\title{
https://doi.org/10.46344/JBINO.2020.v09i5b.05
}

\section{A CLINICAL STUDY TO EVALUATE THE EFFICACY OF AAMLAKI CHURNA WITH MADHU IN THE MANAGEMET OF SHWETPRADARA}

VD. Vishakha Vikas Pachore

Associate Professor, Streeroga and prasuti tantra ARAC, Manchi hill, Sangamner

Email: pachore.vikas@gmail.com

\begin{abstract}
Shweta Pradara (Leucorrhoea) is the disease which is characterized by vaginal white discharge. Vaginal white discharge this symptom is present in both physiological and pathological condition, when it becomes pathological it disturbs routine life style of the woman. Most of the women in the early stage will not express the symptoms because of hesitation and their busy schedule. If it is not treated it may leads to chronic diseases like PID (Garbhashaya Shotha etc.) Charaka mentioned Amalaki Choorna along with Madhu and Vata Twak Kashaya Yoni Pichu Dharana. This treatment is used in Shweta Pradara shown positive results, hence a study was under taken to assess its clinical efficacy. 30 diagnosed patients of Shweta Pradara were randomly selected, allocated in three groups. Group A and Group B received Amalaki Choorna with Madhu and Vata Twak Kashaya Yoni Pichu Dharana respectively and Group C received Amalaki Choorna with Madhu followed by Vata Twak Kashaya Yoni Pichu Dharana for 15 days.
\end{abstract}

Keywords: Aamlki churna, Shweta Pradara. 
Woman surpassing through different stages and phases of life in such a competitive and mechanical world prospers the household and society and as a professional \& responsible citizen, she has to fulfill the dual responsibility for which she needs perfect physical and psychological health, which in real disturbs her quality of life \& causes discomfort, and also affects the general condition of health leading to stress \& malnutrition. Safe, healthy and confident life is very much necessary, for that every woman needs a healthy yoni \& in a virgin nature, by itself, it preserves the healthy status of yoni. Yoni is the factor of paramount importance in life of woman as it being the copulatory organ \& delivery channel, if gets vitiated, there is a fear of vitiation of entire kshetra, which is the need of growing embryo and to produce a healthy progeny. Female genital system starting from Vulva to Uterus is described as Trayavarta yoni which resembles with the mouth of Rohu fish.1 Garbhashaya and Artavavahini dhamani are moola sthana of Rajovaha strotas (Artavavaha strotasa), which is the Bahirmukha strotas.

Any changes in color, consistency, amount, smell of discharge may be a sign of a vaginal infection. Vaginal infections are very common during reproductive period of women. Ayurveda, an ancient science of life is enriched with the knowledge of gynecological disorders related to vaginal discharges which may be blood stained or pinkish, mucoid, purulent, white-thin, thick, curdy or watery. White vaginal discharge is known as
Swetapradara in Ayurvedic classics. The "word" Sweta pradara has not described in Brihatrayee i.e. Charaka Samhita, Sushruta Samhita, Astanga Hridaya and Astanga Sangraha. For white vaginal discharge, the word Sweta Pradara has described in Sharangadhara Samhita, Bhava Prakash, Yoga Ratnakara and in commentary on Charaka Samhita by Chakrapani. 4 Sweta Pradara (Leucorrhoea) is observed as a symptom of so many diseases. Shweta pradara may be present as an upadrava of other vyadhi.5 Since Sweta Pradara is a symptom, not a disease, hence etiopathogenesis of principal disease would be etiopathogenesis of Sweta Pradara also. Considering clinical features of Shweta pradara, we can say that it is a Kaphaja disorder in the region of Apana vayu as any type of strava (discharge) is resulted from Kapha dosha. So, it may be said that vitiated Kapha due to its various factors, results in white discharge through vagina, because of Drava guna and Rasadushthi caused by Kapha. Along with Kaphadushti and Rasadushti, Vatadushti is also present in Shweta pradara. Coitus in excessive amount, frequent abortions (MTP), improper lifestyle and improper dietary habits during menstruation and ovulatory period; along with unhygienic vaginal conditions are commonly observed causes for Shweta pradara (Leucorrhoea). Infections due to certain organisms in vagina and uterus also lead to white discharge due to injury caused by infections.

Patient was treated till the symptoms get completely reduced. She has followed 
schedule of Yoni prakshalana, medicines and pathyaapathya properly. It was observed that, symptoms were started to reduce gradually. At every follow up we observed reduction in symptoms as compared to previous follow up. At the end of day 30 all symptoms were vanished. Follow up wise decrease in symptoms is shown in Table no 1. After six months patient came to OPD for another complaints, she reported that she didn't suffered from previous complaints again. As Shweta pradara is not explained as a separate disease. Its samprapti and samprapti ghataka were determined using Anukta vyadhi Siddhant. Samprapti ghataka were - Dosha: Kapha, Vata Dushya: Rasa, Mamsa; Strotasa: Rasavaha, Artavavaha; Marga: Abhyantatar; Mahabhuta: Pruthwi, Jala; Udbhavasthana: Pakvashaya samutthaja; Samprapti prakar: Atistrava, Vimarga gamana. Plan treatment of this patient was based on etiopathogenesis. Kapha is main samprapti ghataka in Shweta pradara. Along with Kapha, there is Rasa dhatwagnimandya and vitiation of Apana vavyu. Nygrodhadi Gana drugs are of astringent property and hence their use is beneficial.13 Kapha shamaka, stambhaka, Kashaya rasatmaka, astringent, antiseptic and vrana ropana (wound healing) drugs help in increasing local cell immunity and prevent recurrence of symptoms in patients.14 The drugs having abovesaid properties and which are classically indicated were used for Yoni prakshalana and Shamana chikitsa. Properties of ingredient are - Devadaru is Katu-Tikta rasatmaka, Laghu, Ushna, Tikshna, and Katu vipaki. It is Varnya, Kushthahara,
Kapha-pitta shamaka, Raktashuddhikara, Shothaghna and indicated in Pradara. Amalaki is Pancha rasatmaka, Laghu, Anushna, Snigdha, Madhura vipaki. Its Rasayana, Tridosha shamaka, Anulomaka, Balya,

Raktashuddhikara, Raktastambhaka, Shwasaghna, and indicated in Pradara. Lodhra is Kashaya rasatmaka, Laghu, Shita, Snigdha Katu vipaki. It is Kapha-vatagna, Stambhaka, Balya, Raktapittahara, and indicated in Pradara. Nyagrodha, is Kashaya rasatmaka, Laghu, Shita, Snigdha Katu vipaki. Its Kapha-vatagna, Stambhaka, Balya, Raktapittahara, and indicated in Pradara. Chakramard is Amla rasatmaka, Laghu, Shita, Snigdha Amla vipaki. It is Kaphavatagna, Raktashuddhikara, Balya, Raktapittahara, and indicated in Pradara. Pravala pishthi is Madhura, Ushna, Ruksha. It is Grahi, Pittahara, Raktastambhaka, Pittvata anulomana and indicated in Pradara.

\section{CONCLUSION}

Shweta pradara mentioned in Ayurvedic literature and Leucorrhoea mentioned in modern Gynecology closely resemble with each other.

\section{REFERENCES}

Acharya Vidyadhar Shukla., Charaka Samhita by Agnivesha Revised by Charaka and dradhabala with Ayurveda dipika commentary of chakrapanidatta. Reprint ed., Krishnadas academy, Varanasi, 2000:p.751.

Acharya Vidyadhar Shukla., Charaka Samhita by Agnivesha Revised by Charaka and dradhabala with Ayurveda 2020 September Special Issue Edition | www.jbino.com | Innovative Association 
dipika commentary of chakrapanidatta. Reprint ed., Krishnadas academy, Varanasi, 2000:p.767.

Acharya Vidyadhar Shukla., Charaka Samhita by Agnivesha Revised by Charaka and dradhabala with Ayurveda dipika commentary of chakrapanidatta. Reprint ed., Krishnadas academy, Varanasi, 2000:p.768.

\section{Acharya Vidyadhar Shukla., Charaka} Samhita by Agnivesha Revised by Charaka and dradhabala with Ayurveda dipika commentary of chakrapanidatta. Reprint ed., Krishnadas academy, Varanasi, 2000:p.768.

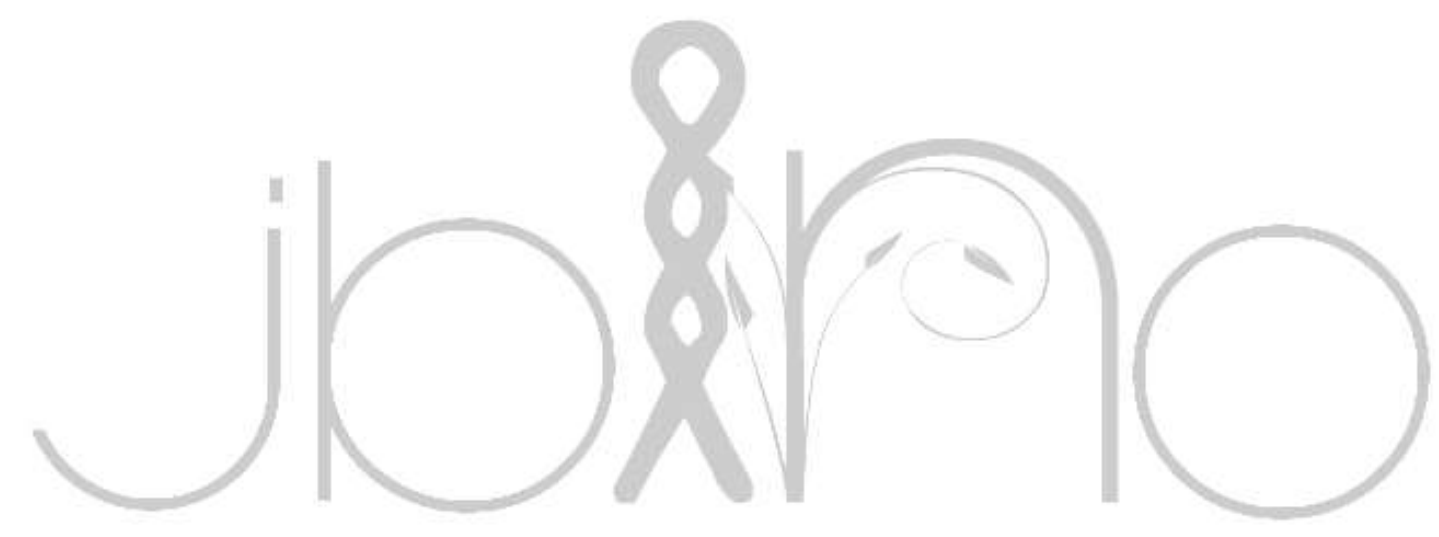

